\title{
Research Article \\ GENETIC STUDIES FOR SEED YIELD AND COMPONENT TRAITS IN MUSTARD (Brassica juncea L)
}

\author{
BALWAN RALIYA ${ }^{1 *}$, KAMLESH KUMAR ${ }^{2}$, RAMESH $^{1}$, PUKHRAJ ${ }^{1}$, JAT RAKESH ${ }^{1}$, MEENA H.S. ${ }^{3}$ AND MUNDIYARA R. ${ }^{4}$ \\ ${ }^{1}$ ARS, Agriculture University, Jodhpur, Mandore, 342304, Rajasthan, India \\ 2AICRP (PM), Agriculture University, Jodhpur, Mandore, 342304, Rajasthan, India \\ 3ICAR-Directorate of Rapeseed-Mustard Research (DRMR), Bharatpur, 321303, Rajasthan, India \\ ${ }^{4}$ College of Agriculture, Nagaur, 341001, Agriculture University, Jodhpur, Mandore, 342304, Rajasthan, India \\ ${ }^{*}$ Corresponding Author: Email - balwanraliya@gmail.com
}

Received: May 09, 2018; Revised: May 24, 2018; Accepted: May 26, 2018; Published: May 30, 2018

\begin{abstract}
Analysis of variance mean sum of square due to genotypes were significant for all the traits studied. These present findings indicated that epistasis plays an important role in the inheritance of different characters in Indian mustard. Therefore, the epitasis interaction effects cann ot be ignored, and the genetic model employed must account for the estimation of inter allelic interactions. Otherwise, the estimates are liable to biased and misleading. Triple test cross analysis also revealed the significant contribution of additive and dominance variation for characters under study. Predominance of non-fixable genetic effect including epistatic effects indicated the perceptible advantage of heterozygosity for enhanced expression of siliqua on main shoot, siliqua length, seed/siliqua and seed yield. Analysis of variance indicated significant values of total epistasis for all the traits except number of secondary branches. The homogeneity of the interactions of 2 variances $(i+$ block and $j+\mid x$ block) was non-significant for all the traits suggesting homogeneity of interaction variances. The partitioning of epistasis into $\mathrm{i}$ type (additive $\mathrm{x}$ additive) and $\mathrm{j}+\mathrm{I}$ type (additive $\mathrm{x}$ dominance and dominance $x$ dominance) epistasis indicated the involvement of both type of epistasis for days to flowering, days to maturity and seed yield.
\end{abstract}

Key words- Oilseed crops, Seed yield, Heterozygosity

Citation: Balwan Raliya, et al., (2018) Genetic Studies for Seed Yield and Component Traits in Mustard (Brassica juncea L). International Journal of Genetics, ISSN: 0975- 2862 \& E-ISSN: 0975-9158, Volume 10, Issue 5, pp.-412-414.

Copyright: Copyright@2018 Balwan Raliya, et al., This is an open-access article distributed under the terms of the Creative Commons Attribution License, which permits unrestricted use, distribution and reproduction in any medium, provided the original author and source are credited.

\section{Introduction}

Oilseed crops are the second most important determinant of Indian agricultural economy, next to cereals with the distinction of highest production and consumption. Indian vegetable oil economy is the fourth largest in the world after USA, China and Brazil. Despite being the fifth largest oilseed producing country in the world, India is also one of the biggest importers of vegetable oils [1]. The mustard belongs to Brassicaceae family which also comprises many economically important edible \& non-edible oilseeds, vegetables, condiments and fodder crops. The oleiferous Brassica species, commonly known as rapeseed-mustard, is one of the economically important agricultural commodities and plays a key role in Indian economy. Indian mustard (B. juncea L.) is a major rabi oilseed crop of the Indian subcontinent occupies more than $80 \%$ of the total rapeseed-mustard cultivated area. Contributes nearly $27 \%$ of edible oil pool in India and accounts for more than $13 \%$ of the global edible oil production [2]. Despite achieving impressive productivity gains through development of various improved cultivars and few hybrids; there is compelling need to further increase and stabilize the productivity of Indian mustard as the productivity of this crop is still low in India, which is a serious concern to plant breeders.

Seed yield is a very complex trait that possess many components which finally result in a highly plastic yield structure. There are large numbers of component traits contributing to the final yield. Knowledge about genetic factors responsible for the inheritance of yield contributing characters, for which there is a great genetic variability in the germplasm collections, is essential for any applied breeding programme. Despite six decades of research about the type of gene action and gene effects, there is still debate about the type of gene action predominating for important traits as it varies depending upon the source of genotypes and the evaluation environments.
Almost all the previous studies have been conducted using parental material not as diverse as those now available with rapeseed-mustard research programme at ICAR-DRMR, which were included in the present study. Amount and type of epistasis can have a major consequence on both the reliability of predictions and the design of breeding programme. Statistically, detection of epistasis using generation means analysis is more reliable and efficient than by the analysis of variance approach [3]. However, it has its own limitations and several assumptions. Triple test cross is a powerful method of genetic analysis, which provides unbiased estimates for epistasis and when epistasis is absent, it also estimates the additive and dominance components of variations with high precision [4]. The knowledge of genetic correlation, which occurs between characters, can help the breeder to improve the efficiency of selection by using favorable combinations of traits and to minimize the retarding effect of negative correlations. Keeping these facts in view the present investigation was conducted to study the inter relationship of seed yield \& different contributing traits and type of gene action involved in the inheritance of traits in Indian mustard based on Triple Test Cross Analysis.

\section{Materials and Methods}

Two genetically diverse genotypes (NPJ 112 and RRN 727) of $B$. Juncea having various desirable traits were selected and a F1 cross NPJ $112 \times$ RRN 727 was generated during 2013-14. The two parents, F1 and 9 promising genotype selected as lines were planted in crossing block during Rabi 2014-15 and 27 crosses were generated in triple test cross fashion. All these materials have been already generated under regular rapeseed-mustard breeding programme of ICARDRMR, Bharatpur. 
Table-1 Analysis of variance (mean squares) for the test of epistasis in triple test cross analysis for 12 traits

\begin{tabular}{|c|c|c|c|c|c|c|c|c|c|c|c|}
\hline Source of variation & D.F & $\begin{array}{l}\text { Day of } \\
\text { flowering }\end{array}$ & $\begin{array}{l}\text { Day of } \\
\text { maturity }\end{array}$ & $\begin{array}{l}\text { Plant } \\
\text { height } \\
\text { (cm) }\end{array}$ & $\begin{array}{l}\text { Number of } \\
\text { primary } \\
\text { branches } \\
\text { /plant }\end{array}$ & $\begin{array}{l}\text { Number of } \\
\text { secondary } \\
\text { branches } \\
\text { /plant }\end{array}$ & $\begin{array}{l}\text { Number of } \\
\text { siliquae on } \\
\text { main } \\
\text { shoot }\end{array}$ & $\begin{array}{l}\text { Siliqua } \\
\text { length } \\
\text { (cm) }\end{array}$ & $\begin{array}{l}\text { Number } \\
\text { of seeds } \\
\text { /siliqua }\end{array}$ & $\begin{array}{l}1000- \\
\text { Seed } \\
\text { weight } \\
\text { (g) }\end{array}$ & $\begin{array}{l}\text { Seed } \\
\text { yield/ha }(\mathrm{kg})\end{array}$ \\
\hline i type Epistasis & 1 & $293.37^{* *}$ & $1032.93^{*}$ & 1365.33 & $98.61^{*}$ & 7.26 & 1317.4 & 0.76 & 1.61 & 1.47 & $1268276.4^{*}$ \\
\hline j+l type Epistasis & 8 & $127.04^{* *}$ & $801.34^{* *}$ & 2984.05* & 11.62 & 128.09 & $749.6^{*}$ & $2.40^{* *}$ & $29.64^{*}$ & $3.03^{* *}$ & $2925430.7^{* *}$ \\
\hline Total Epistasis & 9 & $145.52^{\star *}$ & $827.07^{* *}$ & $2804.20^{*}$ & $21.29^{* *}$ & 114.67 & $812.69^{*}$ & $2.22^{\star \star}$ & $26.53^{*}$ & $2.86^{* \star}$ & $2741302.4^{* *}$ \\
\hline i type Epistasis $\times$ blocks & 2 & 1.37 & 50.7 & 1184.78 & 2.08 & 140.48 & 134.3 & 3.42 & 7.12 & $0.20^{*}$ & 56283.18 \\
\hline j+l type Epistasis $\times$ blocks & 16 & 1.41 & 154.62 & 853.77 & 4.66 & 80.79 & 275.93 & 0.21 & 10.001 & 0.04 & 45144.37 \\
\hline Total Epistasis $\times$ blocks & 18 & 1.41 & 143.07 & 890.55 & 4.38 & 87.42 & 260.2 & 0.57 & 9.68 & 0.05 & 46382.01 \\
\hline
\end{tabular}

Table-2 Analysis of variance (mean squares) for sums and differences, additive $(D)$ and dominance $(H)$ components, degree of dominance $(H / D)^{1 / 2}$ and direction of dominance (r) for important traits

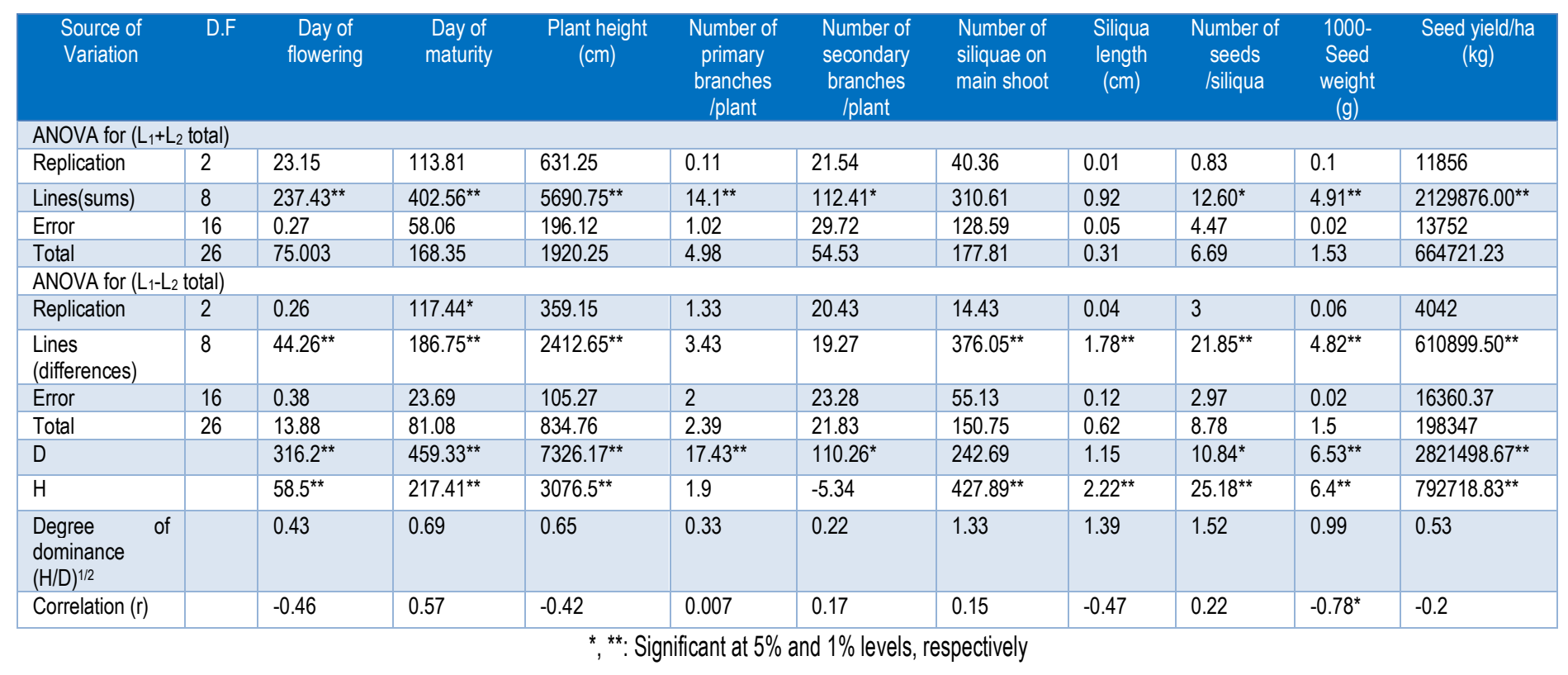

The experimental material consisted of 39 genotypes of Indian mustard $(B$. juncea) involving 3 testers (NPJ 112, RRN 727 and their F1), 9 lines (RH 749, RH 406, Rohini, NRCDR 2, NRCHB 101, DRMRIJ-31, SEJ-2, DRMR 2019, and DRMR 2035), and 27 crosses including 18 single and 9 three-way crosses. The crosses along with testers and lines were planted in randomized complete block design with three replications during Rabi 2015-16. All 39 treatments (lines, testers, and crosses) were raised in rows of $4.5 \mathrm{~m}$ length with $30 \mathrm{~cm}$ between rows and $15 \mathrm{~cm}$ between plants, where each treatment was represented by two rows. Standard agronomic practices were followed to raise the good crop. Recommended doses of fertilizers viz., $80: 40: 40: 40 \mathrm{~kg}$ ha-1 of $\mathrm{N}: P: K: S$, respectively, were applied and irrigated thrice including pre-sowing irrigation.

\section{Results and Discussion}

ANOVA revealed that mean sum of squares due to genotypes (treatments) were significant for all the traits studied. Therefore, a general conclusion can be that there is considerable amount of genetic variability for various traits among different parental genotypes and crosses. Similarly, the genetic variability for various traits in Indian mustard has been reported by many workers [5-11]. Analysis of variance indicated highly significant differences among the treatments, between crosses, parents, lines and testers e in crosses and few traits in testers [Table-1]. This indicated that considerable genetic variation exists among the lines, testers, and hybrids. Similarly, high significant difference was also exhibited between first parent (P1) and second parent (P2) for major yield contributing traits clearly indicated that $\mathrm{P} 1$ and $\mathrm{P} 2$ testers are genetically diverse and would provide an estimate of additive and dominance variation with equal precision. Mean sum of squares due to line $v / s$ testers \& parents $v / s$ crosses and effects due to lines, testers and line $x$ tester were also significant for most of the traits. Therefore, a general conclusion can be that substantial genetic variability exists for various traits amongst the material studied and the lines and testers selected would provide precise information on presence or absence of epistasis and estimates of components of genetic variation. Similar results have also been reported in rapeseed mustard with different set of materials $[12,13]$. The test of significance of differences, $L 1 i+L 2 i-2 L 3 i$, provides the information about presence or absence of epistasis [Table-2]. Therefore, L1 $\mathrm{i}+\mathrm{L} 2 \mathrm{i}$-2L3i for each line, each character and each replication were estimated and tested. ANOVA revealed the significant values of total epistasis for all the traits except for secondary branches. The test of epistasis indicated that most of the traits were affected by epistasis except number of secondary branches, which were not affected by epistasis and only additive gene action (D) was involved in their inheritance. This suggested that improvement in number of secondary branches could be achieved through standard selection procedures. Mall and Bhajan emphasized the role of epistasis for several traits including seed yield [13]. Non-significant interactions variances for $i+$ block and $j+I x$ block for all the traits suggested the homogeneity of interaction variances. Further partitioning of epistasis indicated the involvement of both type $\mathrm{i}$ type (additive $\mathrm{x}$ additive) and $\mathrm{j}+\mathrm{I}$ type (additive $\mathrm{x}$ dominance and dominance $x$ dominance) of epistasis for days to flowering, days to maturity and seed yield. While only $i$ type epistasis for number of primary branches and $j+1$ type for plant height, number of siliqua on main shoot, siliqua length, seeds I siliqua and 1000-seed weight Further, these findings also confirm the earlier findings of $[12,13]$ in rapeseed mustard crops for various traits. The estimates of sums (L1+L2) and differences (L1-L2) totals and their ANOVA provided the means for estimating $\mathrm{D}$ and $\mathrm{H}$ components and degree of dominance [Table-2]. 
The correlation coefficients obtained between sums and differences showed the direction of dominance. The results exhibited the role of both $\mathrm{D}$ and $\mathrm{H}$ components in the inheritance of days to flowering, days to maturity, plant height, number of seeds / siliqua, 1000-seed weight and seed yield while only D (additive) component was significant for number of primary and secondary branches and only $\mathrm{H}$ (dominance) component was significant for number of siliqua on main shoot and siliqua length. It is also stressed upon the role of both $D$ and $H$ components in genetic control of the various characters [12-14]. The estimates of $D$ and $H$ components revealed the higher magnitude of $D$ component for days to flowering, days to maturity, plant height, number of primary branches, number of secondary branches and 1000-seed weight. Similarly, the higher magnitude of $\mathrm{H}$ was obtained for number of siliqua on main shoot, siliqua length, number of seeds I siliqua and seed yield. Thakral, et al., reported the presence of both additive and non-additive genetic components \& more importance of additive component for 1000-seed weight and length of main shoot [15]. Shweta, et al. also reported the importance of both additive and non-additive genetic components for various traits [16]. The estimates on degree of dominance (H/D)1/2 exhibited over dominance for number of siliquae on main shoot, siliqua length and number of seeds / siliqua. Incomplete or partial dominance for days to flowering \& maturity, plant height, number of primary \& secondary branches and seed yield. 1000-seed weight revealed values very near to complete dominance ( 0.99 and 0.98$)$. Rai, et al. and Mall and Bhajan reported partial dominance to over-dominance for traits which supports the findings of the present study $[17,13]$. The negative and significant correlation between sums and differences for 1000 -seed weight $(r=-78$ ) indicated that direction of dominance was towards higher seed size. All other traits exhibited non-significant correlation indicating no evidence of directional dominance in these lines. This showed that the alleles with increasing and decreasing effects were equally important in contributing towards dominance for most of the characters. Similar results for different traits were reported earlier [13].

\section{Conclusion}

These present findings indicated that epistasis plays an important role in the inheritance of different characters in Indian mustard. Therefore, the epistatic interaction effects cannot be ignored and the genetic model employed must account for the estimation of inter allelic interactions. The epistatic effects have been detected for all the characters with conspicuous presence of non-fixable type of epistasis, $(j+1)$. It is, thus, evident that epistasis was an integral component of genetic architecture of various characters in the pool of material studied. Hence detection, estimation and consideration of this component is important for the formulation of breeding programmes and to determine the genetic cause of heterosis with greater reliance. Hence, we may conclude that epistasis is an integral component of genetic architecture for various traits and has a significant role in the inheritance of different characters under study. So, it is evident that both additive and non-additive gene action was important for all the characters under study even in this often-self-pollinated crop. In such cases a breeding strategy which would enable to utilize maximum proportion of fixable genetic variation (additive and additive $x$ additive epistasis) as well as non-additive genetic components (dominance, additive $x$ dominance and dominance $x$ dominance) would be effective. To make an effective breeding programme, biparental mating among randomly selected plants in F2 and subsequent generation would help in pooling the desired genes together to develop pure lines. Further crossing of these lines would help in exploiting non-additive genetic components of variation to develop hybrids, if commercially feasible. Also, recurrent selection and selective diallel mating might be effective to exploit additive $\mathrm{x}$ additive type of epistasis. $\mathrm{j}:$ : Additive $\mathrm{x}$ dominance epistasis

I: Dominance $x$ dominance epistasis

$D$ : Additive genetic variance

$\mathrm{H}$ : Dominance genetic variance

$L$ : Lines

Acknowledgement / Funding: Author thankful to ICAR- Directorate of Rapeseed-Mustard Research (DRMR), Bharatpur, 321303, Rajasthan, India and Agriculture University, Jodhpur, Mandore, 342304, Rajasthan, India.

\section{*Research Guide: Dr H S Meena}

Institute: ICAR-Directorate of Rapeseed-Mustard Research (DRMR), Bharatpur, 321303, Rajasthan, India

Research project name or number: MSc Thesis

\section{Author Contributions: All author equally contributed}

Author statement: All authors read, reviewed, agree and approved the final manuscript

\section{Conflict of Interest: None declared}

Ethical approval: This article does not contain any studies with human participants or animals performed by any of the authors.

\section{References}

[1] Meena H.S., Meena P.D. and Kumar V. (2013) Krishi Bharti, a Monthly Magazine of Rural India, 4(2), 5-7.

[2] Meena H.S., Ram B., Kumar A., Singh B.K., Meena P.D., Singh V.V. and Singh D. (2014) J. Oil. Brassica, 5(2), 134-140.

[3] Lamkey K.R. and Lee. M. (1993) Proceedings of tenth Australian plant breeding conference, Gold Coast, 1, 104-115.

[4] Kearsey M.J. and Jinks J.L. (1968) Int. Theory Heredity, 23, 403-409

[5] Khan F.A., Younas M. and Mustafa G. (2005) Int. J. Agric. \& Bio., 7(2), 257-259.

[6] Kardam D.K. and Singh V. V. (2005) J. Spices \& Aromatic Crops, 14(1), 56-60.

[7] Bhutto L.A., Ansari B.A., Soomro Z.A and Memon S. (2006) Pak. J. Agri., 22(1), 21-25.

[8] Kumar S. and Misra M.N. (2007) Int. J. Plant Sci., 2(1), 188-190.

[9] Misra A.K., Manohar S.S., Kumar A. and Singh K. (2008) J. Oilseeds, 33(2), 187-189.

[10] Yadava D.K., Giri S.C., Vignesh M., Vasudev S., Yadav A. K., Dass B., Singh R., Singh N., Mohapatra T. and Prabhu K.V. (2011) Indian J. Agri. Sci., 81(8), 712-716.

[11] Meena H.S., Kumar A., Ram B., Singh V.V., Singh B. K., Meena P.D. and Singh D. (2015) J. Agri. Sci. \& Tech., 17, 1861-1871.

[12] Singh P., Saharan R.P. and Singh D. (2008) Ans. Agri. Bio. Res., 13(1), 39-48.

[13] Mall A.K. and Bhajan R. (2015) Prog. Agri., 15(1), 99-103.

[14] Chaurasia R.K. and Bhajan R. (2015) Tred. Bio sci., 8(1), 251-255.

[15] Thakral N.K., Joghee N., Singh D., Dhawan K. and Chandra N. (2008) Natnl. J. PI. Improv., 10(2), 83-87.

[16] Shweta, Ranjeet and Singh P., (2007) Asian J. Bio Sci., 2(1/2), 59-62.

[17] Rai S. K., Verma A. and Pandey D. D. (2005) PI. Arch., 5(1), 69-75.

Application of research: It will be helpful tool for researchers for development of new high yielding combinations in Indian mustard.

\section{Research Category: Mustard Breeding}

\section{Abbreviations:}

$r$ : Correlation coefficients

$\mathrm{i}$ : Additive $\mathrm{x}$ additive epistasis 